\title{
Towards Endogenous Livestock Development: Borana Pastoralists' Responses to Environmental and Institutional Changes
}

\author{
Sabine Homann • Barbara Rischkowsky • \\ Jörg Steinbach • Michael Kirk • Evelyn Mathias
}

Published online: 18 July 2008

(C) Springer Science + Business Media, LLC 2008

\begin{abstract}
Borana pastoralists in southern Ethiopia are faced with the challenge of developing more efficient and sustainable use of natural resources. In past decades poorly adapted development interventions and inadequate land-use policies aggravated by population growth have weakened pastoral rangeland management. Ignoring pastoralists' technical and organizational capacities has contributed to progressive land degradation, the erosion of social structures and poverty. The Endogenous Livestock Development concept recognises pastoralists' indigenous knowledgebased strategies and priorities, and uses them as the bases for further development of their production system and social relations, to be utilized, improved and combined with
\end{abstract}

S. Homann · B. Rischkowsky $\cdot$ J. Steinbach

Department of Livestock Ecology,

Justus-Liebig-University Giessen,

Ludwigstr.21,

35390 Giessen, Germany

M. Kirk

Institute for Cooperation in Developing Countries,

Philipps-University Marburg,

Am Plan 2,

35032 Marburg, Germany

E. Mathias

League for Pastoral Peoples and Endogenous

Livestock Development,

Müllenberg 5a,

51515 Kürten, Germany

\section{S. Homann $(\square)$}

International Crops Research Institute for the Semi-arid Tropics (ICRISAT),

P.O. Box 776, Bulawayo, Zimbabwe

e-mail: s.homann@cgiar.org modern technologies. This paper explores the Borana pastoralists' adaptive strategies for improved utilization of natural resources and the manner in which they respond to environmental risk and external influences such as water development and new formal administration. The adaptive responses include controlled integration of crop production and protection of grazing reserves, as well as changing cattle breeding priorities and the adoption of camel husbandry. The pastoralists have started negotiations with the administration to regain control of land utilization by strengthening directives for settlements, land use pattern and extraction rates. To support these initiatives the study recommends that pastoralists and other stakeholders enter into an institutionalized process of negotiation that builds on indigenous knowledge and organizational structures and facilitates validation and implementation of newly generated knowledge.

Keywords Indigenous knowledge · Pastoralists ·

Natural resource management - Institutional development .

Ethiopia

\section{Introduction}

Changing conditions force pastoralists to intensify the management of increasingly scarce rangeland resources. This contrasts with the nature of pastoral systems, which rely on extensive land use and a low population density. However, pastoral rangeland management varies with the availability of grazing and water resources, in adaptation to highly erratic and unpredictable rainfalls. Pastoralists thereby generated deeply rooted, decentralized indigenous knowledge (IK) that influenced short-term responses and long-term management strategies, and enabled them for 
typically opportunistic range management (Sandford 1983; Roe et al. 1998).

Amongst pastoralists in East African rangelands the Borana rangeland management system in southern Ethiopia was regarded to be especially productive. As part of this management system, Borana pastoralists specialized on extensive cattle keeping, exploring rangelands with seasonal herd mobility. Cooperative networks amongst herders helped to mitigate risks and solve conflicts. The limited supply of permanent water confined at clusters of deep wells in the central area allowed them to control access to the adjacent Borana rangelands (Cossins and Upton 1987; Helland 2000).

However, today the productivity of the Borana rangelands is deteriorating, caused by a growing imbalance between the human population, livestock and natural resource stock. The growth of the human population (from $1-1.3 \%$ at the early 1970 s compared to $2.5-3 \%$ in the late 1980s) has increased the pressure on the natural resources and severely reduced the livestock per person ratio (Helland 2000). Recurrent droughts have aggravated the problem and caused further loss of livestock and grazing resources, as well as unsustainable exploitation of the remaining resources. As a result of these combined factors, the Borana rangelands were severely degraded, important social structures were destroyed, endangering food security for many Borana households (Coppock 1994; Kamara et al. 2004).

Enormous research and development efforts have been vested in the Borana rangelands since the 1970s. However, development interventions ignored the Borana pastoralists' technological and organisational knowledge in rangeland management, they undermined existing indigenous rangeland use patterns and further contributed to the devastating trends (Bruce et al. 1994; Oba 1998; Kamara 2001):

- The construction of additional watering ponds in traditional rainy season pastures attracted the establishment of permanent encampments within formerly seasonal pastures, disturbing the balance between the human population, cattle stocks, water and forage resources.

- The imposition of a new formal administration, manifested in the peasant associations (PA) of the revolutionary Derg regime after 1974, which was alien to the indigenous institutions interfered with the pastoralists' coordination mechanisms of access to grazing and water resources.

- The regionalisation policy of the central state after 1991 transferred an area of about one third of the Borana rangelands and two important wells to the Somali administrative region, fuelling inter-ethnic warfare between the two pastoral groups.
- The official ban on burning pasture and the establishment of private commercial ranches further exacerbated the disruption of the Borana pastoral system.

- Extension services favoured crop cultivation within valuable grazing areas and claimed key resources from pastoral production.

Today, Borana pastoralists are in transition from traditional pastoralism to a semi-sedentary grazing system, and can no longer make full use of their IK-based rangeland management strategies. Documenting and analyzing the pastoralists IK allows to understand their perception of changes of their local environment and potentially conflicting interests, and to identify technical and organizational elements that can help them cope with variable rangeland resources and socio-economic challenges. This can form the base for Endogenous Livestock Development (ELD), by validating Borana pastoralists' applied IK in rangeland management and identifying gaps for further investigations.

Against this background, this case study explores how the pastoralists have adapted their management strategies to environmental and institutional changes in southern Ethiopia in the past 30 years. The specific objectives are to (1) illustrate the changes in the traditional Borana pastoral landuse system, through external interventions; (2) describe key strategies and institutional arrangements by which Borana pastoralists reacted to these changes in their environment; (3) discuss potentials and constraints in building on pastoralists' IK to achieve intensified rangeland management; and (4) discuss institutional arrangements that can sustain Borana pastoralists' participation in development planning and decision-making processes.

\section{Conceptual Framework}

The conceptual framework for this study refers to three development-oriented research domains that support pastoralists (same as for farmers) in developing rangeland management within their own context:

Land-use dynamics emerged from farming systems research (FSR) in the 1990s and draws attention to the diversity of pastoralists' situations, natural and socioeconomic factors and adaptation processes. It addresses the interactions between natural, social and institutional environments, and the implications for pastoralists' adaptations. The impact of increasing human populations, national policies and increasing market integration on land-use strategies and practices is investigated (Trebuil et al. 1995; Giampietro 1997; Pender et al. 2006). Special emphasis is placed on the need to improve pastoralists' ability to better adapt to changes in their environment and use natural resources in a more controlled way (Sayer and Campbell 2001). 
Indigenous Knowledge-based approaches focus on pastoralists' collective experiences and management skills. IK is defined as the community's information base, which facilitates communication and decision-making. It is dynamic, influenced by local creativity and experimentation and contact with outside (Berkes et al. 1995; Flavier et al. 1995). Sustaining IK assumes that local communities have the competence and skills to identify the most appropriate options of adapting and integrating new technologies. A major restriction of $\mathrm{IK}$ is that it can only be generated through continuous application and active engagement. Its disappearance signals a loss of a community's capacity to manage ecological and socio-economic challenges (de Walt 1994; Ray 1998). This does not necessarily imply that other, new strands of IK gain in importance, which, in turn, allows pastoralists to overcome these challenges. Incorporation of IK into research and development facilitates appropriate technology development, and helps faster and more effective adaptation to complex and dynamic processes.

The Endogenous Livestock Development (ELD) network aims at mobilising exactly these pastoralists' own strengths, skills and resources. ELD acknowledges that most pro-poor livestock development approaches have failed (Geerlings et al. 2002; Mathias et al. 2005; KoehlerRollefson 2007). ELD supports livestock-dependent people to improve their own livelihoods in working further in the well-known fact that pastoral systems, for instance, are primarily geared towards risk aversion. Strategies are looked for that preserve livestock keepers own ability to adapt to changing conditions. ELD is an approach that starts with IK and validates IK, and it integrates local culture with modern technologies, so that pastoralists can make better-informed choices and decisions towards unknown pathways. ELD combines well-established participatory livestock development with institution building, policy development, improved service delivery, strategic networking and lobbying to facilitate this process (van't Hooft et al. 2007). It can, therefore, not be regarded as a new theoretical concept but rather a refocusing and recombining of existing models and concepts by (1) documentation, (2) validation, and (3) operationalisation of IK.

1. Documentation: Documenting IK is a challenge as it is often tacit and embedded in various strategies, community interactions or cultural values (World Bank 1999). Special efforts are required to make technical and organizational IK explicit and to characterize its context. To confine the focus of this study we used Sandford's (1983) definition of opportunistic rangeland management. He identified variable stocking densities, herd mobility and herd diversification as key strategies, which are based on pastoralists IK, and enable them to flexibly adjust livestock nutritional needs to available forage and water resources. ${ }^{1}$

2. Validation: To use IK as a resource for development, it is also necessary to check its relevance and limitations in a changing environment and analyze conditions that encourage people to generate IK for new challenges, and store IK as long as it proves useful to deal within a given context. Transferring IK-based technologies to a different environment requires people to systematically experiment and learn anew (Blaikie et al. 1997). Applying IK in pastoral areas has to account for factors such as rangeland degradation, changes in population density, economic constraints and stochastic events such as droughts, price changes, epidemics and politics (Sandford 2006).

3. Operationalisation: New institutional forms are needed, e.g. negotiation platforms, that physically bring pastoralists' together with researchers, development agents, service providers and policy makers. They would merge IK-based local and outsider's knowledge systems and accommodate different perspectives, capacities and methodologies. They are conceived as continuous learning processes, geared by self-evaluation and discussions about challenges and potentials, and require significant investment in facilitation (Roeling 1994; Blaikie et al. 1997). Involving pastoralists in such joint learning structures can enhance their capacity to adapt to changing conditions. It would support pastoralists to use IK for their own interests, instead of the IK being extracted for outsiders (Bayer and Waters-Bayer 2002).

\section{Study Areas}

The Borana zone covers an area of about $50,000 \mathrm{~km}^{2}$ and is located in the south of the Federal Democratic Republic of Ethiopia (ODPPB 2000). It provides a living for about 350,000 people and hosts about one million head of cattle, small ruminants and camels (Fig. 1). Borana pastoralists are traditionally specialised on semi-sedentary cattle husbandry and bred the Ethiopian Boran cattle (Large East African Zebu breed group). They used to achieve higher land productivity than extensive sedentary beef production (Cossins and Upton 1988).

The Borana rangelands are characterised by an arid and semi-arid climate, with pockets of sub-humid land. The average annual rainfall ranges between 350 and $900 \mathrm{~mm}$,

\footnotetext{
${ }^{1}$ The 'non-equilibrium' model by Ellis and Swift (1988) and the 'state and transition' model by Walker and Noy-Meir (1982) and Westoby et al.( 1989) also describe the relation between variable rainfalls and livestock impact on rangeland resources.
} 


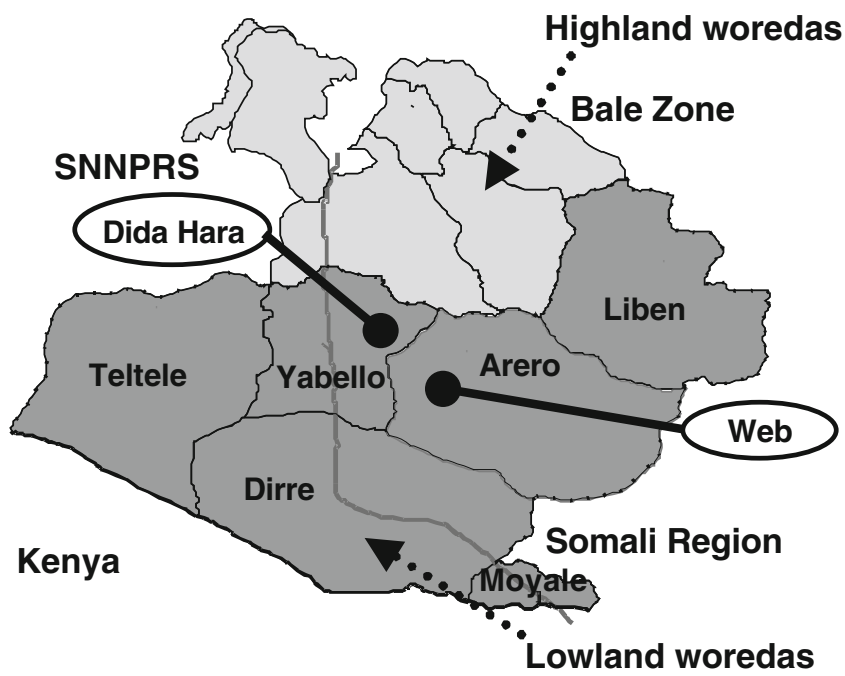

Fig. 1 Dida Hara and Web in the Borana rangelands in southern Ethiopia. Adapted from Homann et al. 2007. SNNPRS South Ethiopian Nations, Nationalities, and Peoples' Regional State. Source: provided by LUPO/GTZ

with a considerable interannual variability of $21 \%$ to $68 \%$ (Kamara 2001). Rainfall is bimodal, $60 \%$ of the rainfall occurs between March and May (main rainy season) followed by a minor peak between September and November (short rainy season). In the past, droughts lasting several years occurred approximately once in 20 years, and isolated dry years $(<400 \mathrm{~mm})$ once in 5 years (Coppock 1994). Recently, the period between droughts has decreased to 7 years, and the latest drought in 1999/2000 occurred only 3 years after the previous one (Homann 2004).

The rangelands are dominated by tropical savannah vegetation with open grasslands, and perennial herbaceous and woody vegetation (Pratt and Gwynne 1977). The vegetation is patchy, due to widely varying soils, temporally and spatially variable rainfalls and differences in the land use history. Cossins and Upton (1987) calculated that the annual primary productivity varies between 270 and 150 tons of dry matter (DM) $\mathrm{km}^{-2}$. Based upon these figures, and the fact that the Borana land use system is semi-sedentary, and stocking densities possibly impact of on rangelands, the authors calculated potential average stocking densities of 23.5 Tropical Livestock Units (TLU) $)^{2} \mathrm{~km}^{-2}$ in years with average rainfall, $17.6 \mathrm{TLU} \mathrm{km} \mathrm{km}^{-2}$ in dry years and $11.8 \mathrm{TLU}$ $\mathrm{km}^{-2}$ in drought years.

In the recent past, however, various factors have contributed to an effective decline in rangeland resources.

\footnotetext{
${ }^{2}$ Cossins and Upton used LSU ( $1 \mathrm{LSU}=230 \mathrm{~kg}$ ) as standard unit for the calculation of potential stocking densities in their paper. They calculated the average adult Boran cattle with $160 \mathrm{~kg}$ live weight as 0.7 LSU. In order to allow easier comparison with stocking densities calculated by other authors, the LSU data were here converted to TLU (1 TLU=250 kg, Jahnke 1982).
}

Woody species encroachment was less than $40 \%$ in the $1980 \mathrm{~s}$, but has increased to $52 \%$ in the early $2000 \mathrm{~s}$. Crop cultivation expanded in most productive rangelands and has induced soil erosion to additional $19 \%$ of the area (Dalle 2004). The average cattle stocking densities have increased to 105 and $43 \mathrm{TLU} \mathrm{km}{ }^{-2}$ during and after the last drought (Homann 2004) ${ }^{3}$, although frequent droughts have depleted the cattle herds in Southern Ethiopia to an extent of $78 \%$ after the previous 1995-1997 drought (Ndikumana et al. 2000). Heavy grazing pressure on remaining rangelands exacerbates the downward trend and contributed to impoverishment of large parts of the Borana population. Desta (1999) noted that the ratio of cattle per person has declined within the last 15 years from an average of about 4.1 head of cattle to 2.25 head of cattle person ${ }^{-1}$. This indicates a major decline in welfare for many households below the minimum food security (Coppock 1994).

The recent changes also affected the complex Borana institutional system, which according to Legesse (2000) used to be a model for African democracy. The traditional institutions integrate social and political control as well as natural resource management (Legesse 1973; Helland 1982; Hogg 1990; Oba 1998; Fig. 2). Accordingly, the social organisation of the Borana pastoralists is determined by genealogy. Clans are dispersed across rangelands and responsible for the management of the deep wells, as well as social security and culture. The political organisation is under the gadda system. The gadda defines rules, obligations and authorities, and thereby it provides a framework for socio-political stability over long times. The spatial organisation follows geographical units. Basic units are stationary encampments with households of five to seven persons (warra), of which temporarily mobile camps (foora) are split off. These units merged into encampment clusters (ardaa), villages (olla), neighbourhoods (reera), common seasonal grazing areas (dheeda), and areas related to permanent water sources (madda).

The study compared two PAs with differences in functionality in the traditional range management system (dry season and rainy season grazing area) and in external interference (Fig. 1). Dida Hara PA was selected as location with strong impact of development interventions. The area was formerly used for rainy season grazing, and surface water was only seasonally available. Permanent watering ponds were constructed in the 1970s; they opened up the area for year-round grazing and uncontrolled settlement. In contrast, Web PA represents a location with comparatively

\footnotetext{
${ }^{3}$ Homann (2004) converted the mixed herds of the Borana pastoralists to TLU by using the conversion factors suggested by other authors for East Africa $(1$ dromedary $=1 \mathrm{TLU}, 1$ cattle $=0.7 \mathrm{TLU}$ and 1 small ruminant $=0.1 \mathrm{TLU}$; Sandford and Habtu 2000).
} 
Fig. 2 Structure of the indigenous institutions in Borana rangelands. Source: Compare text, own design, adapted from Kamara (2001)

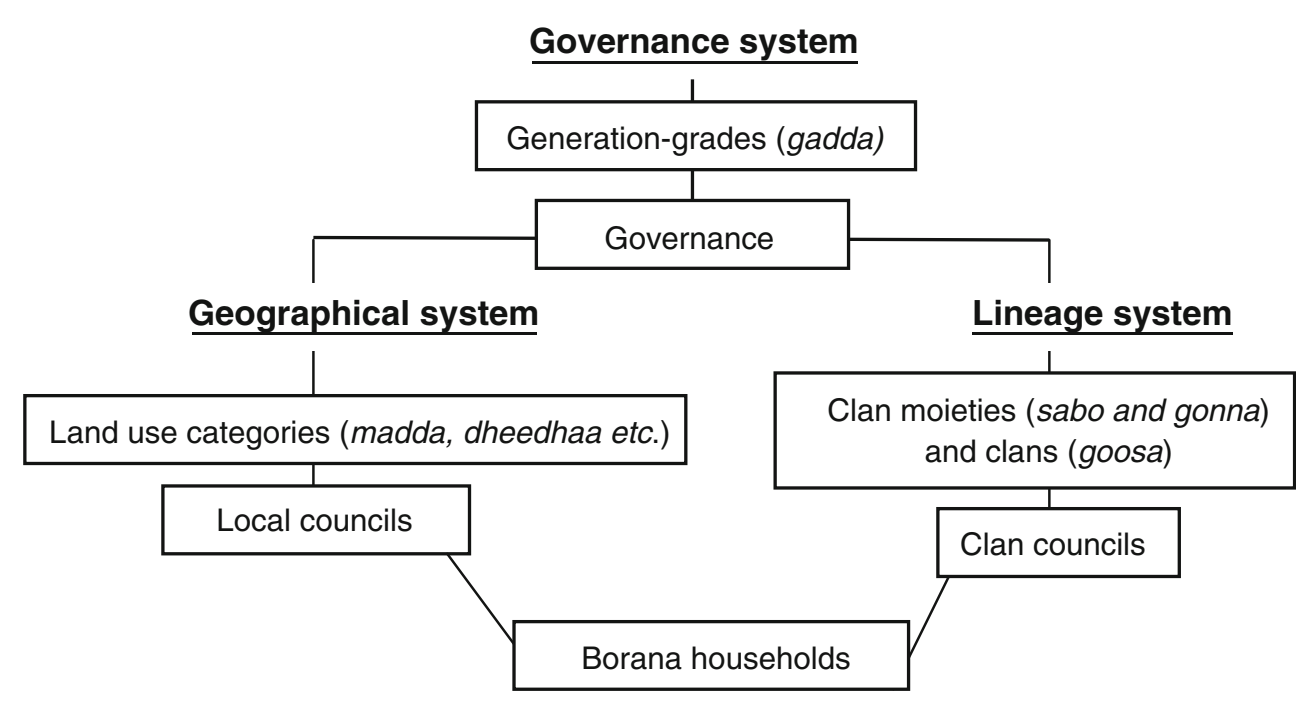

lower effects of interventions. It is a traditional dry season grazing area associated with one of the oldest deep well clusters and a permanent supply of good quality water. Within Dida Hara and Web three encampment clusters (ardaa), were selected for their short, medium and long distance from the respective PA centre and on the basis of accessibility.

Data Collection and Analysis

The study was implemented in cooperation with the Borana Lowlands Pastoral Development Programme (BLPDP/GTZ). Data collection started in December 2000 at the late stage of the 1999/2000 drought and was completed in July 2002.
To analyse the complex changes in the Borana land-use system and to crosscheck pastoralists' information, qualitative and quantitative data collection techniques were combined. The structure of the research process is shown in Fig. 3. First, main problems in rangeland management were identified at introductory community workshops with the pastoralists. Following this, land-use dynamics were evaluated, using participatory rural appraisals (PRA) and quantitative assessments at household and community level, as well as crosschecks with secondary information. Key findings and options for improved rangeland management were then discussed at broader multi-stakeholder levels. Further research and development intervention can take up these findings and recommendations and incorporate them into
Fig. 3 Research process and tools for the analysis of Borana pastoralists' adaptations in rangeland management. For the range condition survey see Dalle (2004)

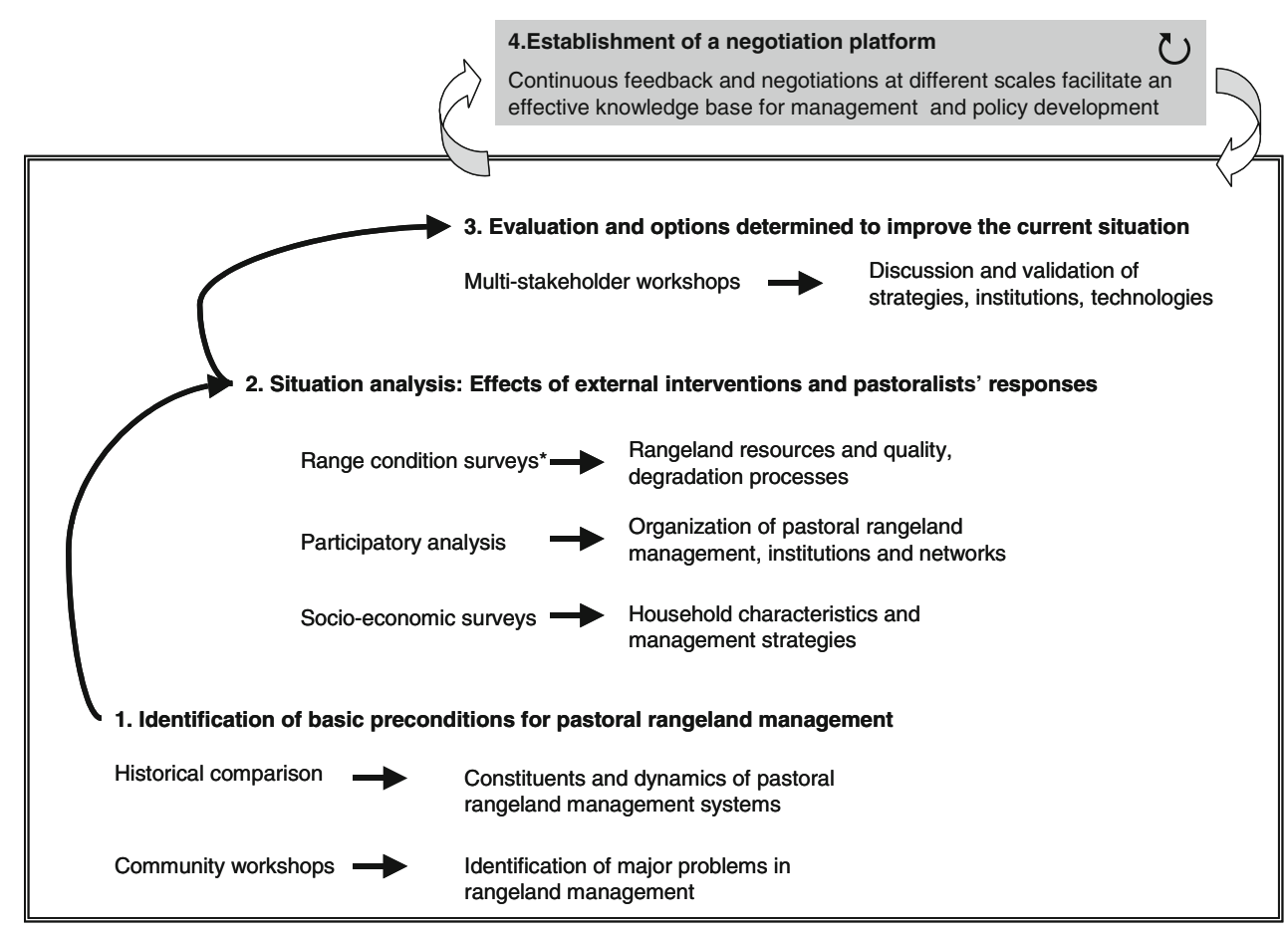


their programs, ideally in a continuous cycle of investigation, evaluation and adaptation (negotiation platforms).

The effects of external interventions and pastoral responses were analysed from a historical perspective. Firstly, present land-use strategies and institutional arrangements in Dida Hara and Web were compared with the situation 30 years ago before external interventions started. Key resource person interviews and small group discussions with knowledgeable elders at the selected encampment clusters (ardaa) provided background information traditional landuse classification, seasonal herd movements and changing land-use pattern for the entire Borana rangelands. Participatory land use mapping gave an overview of the local infrastructure and principal land use categories. Additionally, key persons from within and outside of the communities were asked to demark natural features, indigenous landscape categories and major grazing directions on satellite pictures of Borana rangelands, at a scale of 1:250,000 (Werner et al. 2001). The satellite interpretation was used to verify pastoralists' earlier information and to map principal landuse classification and herd movements for the entire Borana (see Fig. 2 in Homann et al. 2007). These sources of information were combined with Geographical Positioning Systems (GPS) measurements with the assistance of local range scouts (aburru) on the current areas of the selected encampment clusters and local land use categories (see Fig. 3 in Homann et al. 2007).

The current socio-economic situation was assessed in three sets of surveys. Focus group discussions with small groups of elders and herders obtained basic demographic information at the level of the encampment clusters (ardaa). A socio-economic baseline questionnaire comprised a sample with more households in Dida Hara $(n=182)$ than in Web $(n=58)$, in proportion to the size of the human population. In each encampment cluster, $5 \%$ to $10 \%$ of the encampments (olla) and pastoral households were interviewed. An in-depth survey of socio-economic household characteristics was carried out with the above-mentioned sub-sample of selected households in Dida Hara $(n=31)$ and Web $(n=29)$. The questionnaires included aspects of household composition and asset status, sources of income and access to extension service, cooperation in livestock management, herd dynamics by in- and outflows during the last drought (1999/2000) and after the last drought (2001/ 2002), as well as herd composition and herd mobility.

The key strategies that reflect currently applied IK were measured as follows:

- Variability in stocking densities: Focus group discussions with elders and herders at each of the selected encampment clusters (ardaa) produced matrixes with seasonal stocking densities by estimating the total number and size of herding groups that moved in and out of the areas of the encampment clusters for daily grazing. The herding groups were recalled for the seasons of a year with high stocking densities (1997/1998) before the last drought and a year with comparatively low stocking densities (2001/2002) after the drought. The CV (\%) in stocking densities (TLU $\mathrm{km}^{2}$ ) between the seasons was used as an indicator for seasonal variability.

- Herd mobility: Pastoralists were asked to recall herd movements within the above-described socio-economic in-depth survey. They were requested to specify their movements of the different livestock species during and after the last drought (1999/2001 and 2001/2002 respectively), by destinations and distances to their encampments as well as the duration per movement. This allowed comparing the monthly walking distances of the herds within the observation periods. Determining mobility at household level was crosschecked with the picture at the landscape level, and also provided complementary information.

- Herd diversification: The composition of herds was assessed in the course of the same survey, asking for the number of cattle, goats, sheep and camel at the before (1998) and after the last drought (2002).

Changes in breeding priorities of Borana pastoralists were identified by characterising sub-types of the Boran cattle breeds for a randomly selected number of households in Dida Hara and Web. Body weights of a total of 543 animals were estimated from their girth circumference, using a measuring tape developed in Ethiopia directly estimating body weight. The animals were measured during the peak dry and wet season using a representative subset of adult female and male cattle from each breed sub-type. The average body weights of these sub-types were compared and related to preferences of the cattle owners.

The pastoralists' indigenous institutions on natural resource management and changes in the institutional settings were analysed by two community meetings with delegated elders in Dida Hara and Web, and the information obtained during these meetings was compared with secondary information. Venn diagrams demonstrated the actual institutional arrangements compared with the situation about 30 years ago. The elders were split into two equal groups and each group identified all institutions with relevance to natural resource management during the respective period of time. The relative importance of the institutions was symbolised by a large paper (strong importance), a middle sized paper (fair importance) or a small paper (little importance). The symbolised institutions were organised on a large sheet, where distances to the abscissa represented the frequency of contacting them. Finally, the institutions were arranged according to their functional interrelationships, and linkages were drawn for 
the most intensive institutional contacts. The two groups presented their completed Venn diagrams and discussed the differences. The discussions revealed extremely stimulating for the pastoralists to reflect the deteriorating institutional situation.

A series of multi-stakeholder workshops was organised in June-July 2002 as a final stage in the research cycle. The workshops were held at the community, regional, national level to crosscheck the findings, discuss priorities for future development interventions. Workshops at the community level were held in Dida Hara and Web, inviting local elders, herders and women. Workshops at the regional level were held in Yabello and Negelle, and finally at the national level in Addis Ababa, with representatives from the communities, Ethiopian federal government, research, development and NGOs. About 30 to 50 participants attended the one-day workshops. These workshops eventually initiate a dialogue on how to strengthen pastoral range management, a first step to establish negotiation platforms that operationalize IK

\section{Results}

Principles of Borana Pastoralists IK-Based Rangeland Management Before the 1970s

Before the 1970s, Borana pastoralists organised rangeland management across distinct ecological zones and applied large-scale herd movements. This rangeland management, which had been strongly guided by IK, was actively sustained by the Borana pastoral cultural code of conduct (nagaya Borana or peace among all Borana), and was mainly driven by ecological constraints. The limited supply of water at the central area with deep wells (tula) determined the mobile land use pattern. Borana pastoralists in Dida Hara and Web explained that herd movements were regulated by "orally fenced demarcations". Permanent encampments (warra guda) and adjacent pastures for the common use of the lactating herds (lafa haawichaa) were kept clustered to a line at a distance of 10 to $15 \mathrm{~km}$ around the wells (dongora seera). The grass around the encampments was reserved for smaller calves (mara qu'ee). Additional forage banks were reserved for weak and sick animals to use during periods of forage scarcity (lafa seera yabiye). Several encampment clusters shared these reserves and this helped to avoid fragmentation of the rangeland. Pastures within a day's walking distance of about $15 \mathrm{~km}$ were prohibited from any utilisation except grazing and walking (mata tixaa). Several pathways channelled the herds to the watering place (kara oba). The pastures for rainy season and dry season grazing were found in the periphery to these central grazing areas, and they were kept open to move the satellite herds (lafa gue'ssa). Peripheral grazing areas towards other wells were used as last rescue areas during the peak dry season (lafa seera bonna) and the more remote areas, such as Dida Hara, were used during the rainy seasons (lafa seera roba).

Within this system, pastoralists differentiated two types of grazing areas that were used for different herd categories. Warra areas like Web were preserved near the homesteads in the central area of the deep wells, for all year grazing of mainly lactating cows, young and sick animals. Foora areas like Dida Hara were for temporary grazing in the remote rangelands by the non-lactating animals (see Fig. 2 in Homann et al. 2007). Depending on the available grazing and water resources animals could have been shifted between the two area types. Pastoralists thereby reduced grazing pressure in the central area and sustained seasonal grazing areas in the periphery. The variability in stocking densities was consequently high. The herders, by observing and evaluating their natural environment and obtaining information from other herders, knew where to move their animals in order to find forage and water resources.

Strategic negotiations and flexible institutional networks, such as the coordinative bodies for water and grazing management, facilitated herd movements. Large groups of herders had to cooperate for watering the cattle herds at the deep wells, as well as for maintaining and rehabilitating rangeland resources. Access to water was regulated at clan level. Each clan had appointed water managers ( $a b b a$ herrega) for daily administration of the wells. Across clans, special elders' committees coordinated each well with the use of the adjacent pasture (jarsa madda), and other committees coordinated the access of cattle to the shared seasonal grazing areas (jarsa dheedaa). Special meetings were held for the re-partitioning of rainy season pastures (kora dheedaa). The decisions on herd movements were made against the accounts of experienced range scouts and in agreement with knowledgeable elders.

Elders committees at the local level first addressed conflicting claims. More complex issues were transferred to higher levels of spatial organisation, to the clan-level or the gumi Gaayo, the pan-Borana legislative assembly following the principle of subsidiarity. The gumi Gaayo was supported by officials of the indigenous governance system (gadda), and met every 8 years to review the directives for good governance. The clan-affiliated and governance networks ensured a continuous transfer of information, enforcement of agreements and legitimacy of new regulations for every member of the Borana (see Fig. 5 in Homann et al. 2007).

Since the 1970s the conditions have changed. External interventions and the rapid growth of human population, caused by factors such as human health services, increased water supply and re-settlement, affect the pastoral land-use system and have reduced the available grazing resources 
dramatically. Figure 4 at the top illustrates the various external interventions and climatic hazards during the socialist government and during the transitional government. The immediate effects on the land-use system follow this and at the bottom the figure shows pastoralists' responses to it.

Development Interventions in the 1970s and 1980s

The Ethiopian government has started large development interventions in the early 1970s. The main objective was to increase rangeland productivity and exploit pastoral production for the national economy, through infrastructure development (e.g., water ponds, state ranches and road networks, veterinarian services, marketing facilities). It was argued that construction of water ponds in the former rainy season grazing areas would reduce high grazing pressure on the dry season grazing areas. The development plans did however not accommodate practiced pastoral rangeland management. The implementation of the formal administration at PA-level was linked with the establishment of Producer Co-operatives (PC) and Service Co-operatives (SC) for providing input, finance and marketing channels. The PAs concentrated on public security and political control, but gave little consideration to the rangelands. The PA administration and extension services one-sidedly promoted crop cultivation as a means to settle the pastoralists, regardless of the agro-ecological disposition of the Borana rangelands. Furthermore, the Ethiopian
Fig. 4 Land-use dynamics in pastoral systems of southern Ethiopia: External interventions, effects and pastoralists' responses
Before 1974:

IK-based extensive rangeland management Common pastoral identity

Ecological constraints

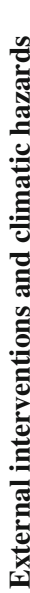

שֶ.

Socialist government (Dergue)

(1974-1991):

- Construction of water ponds

- Creation of Pastoral Associations (PA)

- Ban on rangeland burning

- Promotion of crop cultivation

- Sedentarisation policy

- Infrastructure development
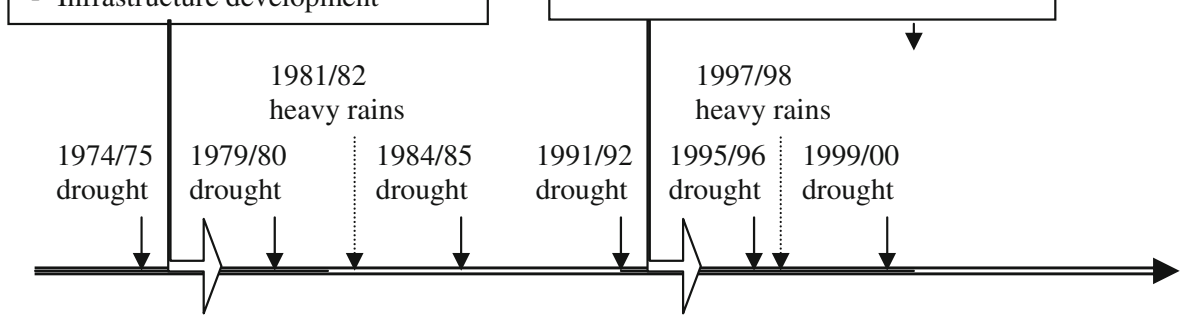

Scattering of permanent encampments

돌

Start of crop cultivation and private grazing

Erosion of functional rangeland categories

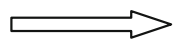

After 2000:

Land-use intensification Livelihood diversification Ecological and socio-economic constraints
Transitional/democratic government (1991-2002):

- Cont. water development

- Cont. PA administration

- Alienation of rangelands and water to Somali Regional State

- Cont. ban on rangeland burning

- Cont. support for crop cultivation

- Cont. infrastructure development

- Relief and rehabilitation

Woody species

encroachment

Increasing

human population density

Declining

human:livestock ratio

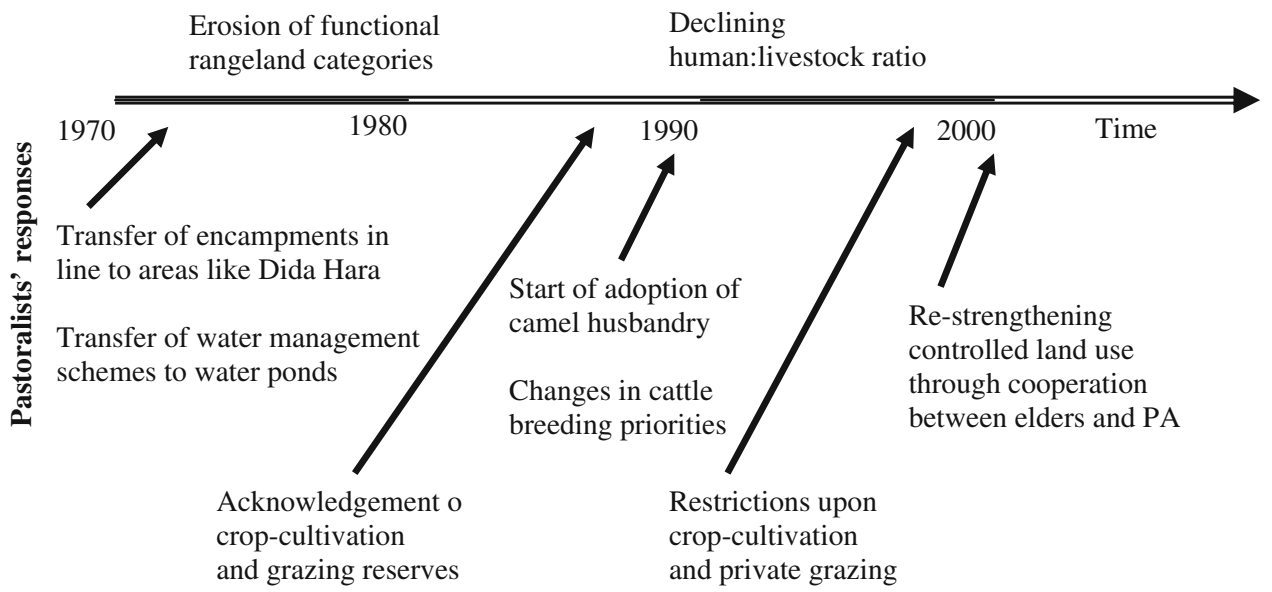


government had issued a proclamation to ban the burning of highland forests, and applied it equally to the pastoral rangelands.

\section{Effects on the Land-use System}

After the construction of additional water dams permanent encampments scattered. Easy access to permanent water and abundant pastures in rainy season areas like Dida Hara made herd movements back to dry season areas like Web no longer necessary. Elders from Dida Hara and Web reported that essentially the wealthier owners of large mobile herds, who had sufficient manpower and food to sustain satellite herds, were the first to establish new encampments in the former rainy season grazing areas, and the former temporary grazing area was gradually converted into permanent grazing. This affected Web, where mainly the smaller herd owners remained. They were deprived of the best rainy season grazing areas for their satellite herds, while during periods of water scarcity Web still has to cope with the demand of external herds.

Furthermore, pastoralists increasingly adopted crop cultivation, particularly after the severe drought of 1984/ 1985. Borana pastoralists probably adopted crop cultivation from neighbouring farming communities such as the Konso tribe, and settler soldiers and immigrant farmers from highland areas introduced crop cultivation at sub-humid pockets in Borana rangelands. Cropland expansion was further supported by the governmental extension services. Additionally, Borana pastoralists fenced off commonly used forage banks (kallo), as practiced by the neighbouring Gujji tribe and were certainly influenced by the establishment of rotational grazing schemes and commercial ranches.

Uncontrolled land use expanded since indigenous rangeland categories lost their functionality in preserving a seasonal grazing system. The distinction of all-year grazing areas (warra) and temporary pastures (foora) are being eroded, and the former long-distance movements associated with a high variability in stocking densities broke up. Dida Hara and Web, sites that were originally linked in a common grazing system, evolved into separate grazing systems.

\section{Pastoralists' Responses}

At this early stage of external interventions three major responses of Borana pastoralists were identified. Firstly, the indigenous principles of clustering encampments in line (dongora seera) were applied to the newly obtained grazing areas in Dida Hara. The encampments were clustered along two lines in parallel to the gravel road from Arero to Yabello and at $12 \mathrm{~km}$ distance (see Fig. 3 in Homann et al. 2007). Pastures between the lines were preserved for grazing the lactating herds and calves, the northern pastures for dry season grazing and the southern for rainy season grazing. The powerful herdsmen in Dida Hara were said to enforce the directives on the new area and the agreements for the home-based grazing areas have been successfully respected until now. Clustering encampments is thus a tool by which pastoralists restrict the fragmentation of communal grazing areas and sustain the applicability of herd mobility. However, disputes about user claims for pasture and water within the grazing area of Dida Hara were resolved by involving the formal administration, including the PAs, and no longer through traditional negotiating institutions.

Secondly, basic principles for indigenous water management were transferred from the traditional deep wells to the newly constructed water ponds and have been sustained over the last 30 years (compare Figs. 6 and 7). In the traditional system the right to water from wells is organised by clan membership (goosa), and requires regular contributions for maintenance and operation. The users of ponds are the adjacent inhabitants, who are also requested for
Fig. 5 Years when interviewed households in Dida Hara and Web started keeping camels

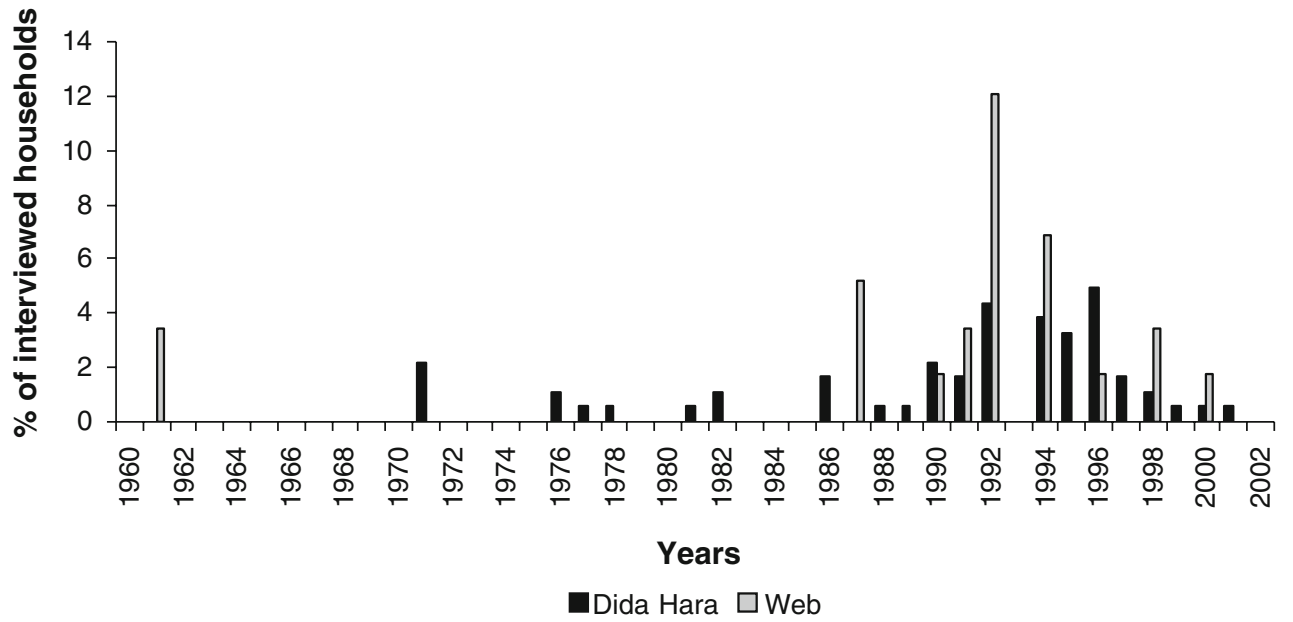




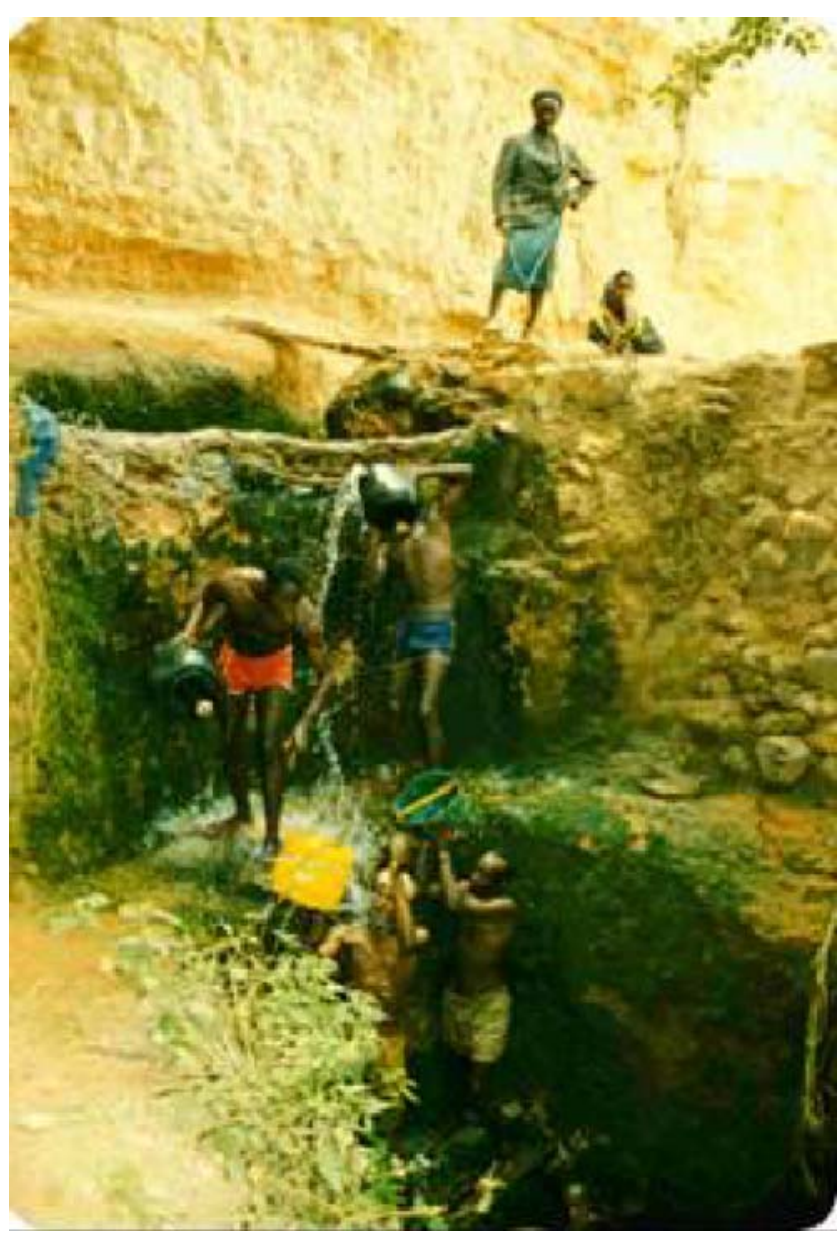

Fig. 6 Traditional water management at a deep well in Web (tula)

these contributions. The water users join in assemblies for common coordination and control (kora hara). Access to water is conditioned to tasks of cleaning, maintenance and rehabilitation. Cattle are not allowed to enter the open pond water, but must drink the water hauled into troughs made on clay soil (naaniga) or where sandy soil prevails by progressive shifting spiny tree branches (merri). Labour invested in water management is thus a tool to control access to the surrounding pastures. Herders who are not directly entitled can obtain user rights through social relationships and in emergency situations.

Third, crop cultivation was acknowledged by the gumi Gaayo in 1988, as a mechanism to cope with increasing food insecurity. The same gumi Gaayo in 1988 approved fenced forage banks as a tool for managing well-defined sites as common grazing reserves, which avoids the fragmentation of the extensive rangelands and preserves grazing for weak livestock during most critical times of the year (Shongolo 1995).

Increasing Scarcity of Grazing Resources in the Recent Past

Within the last 15 years additional factors reduced the available rangeland resources. The regionalization policy of the Ethiopian Government has transferred most valuable grazing and water resources from the Borana to the Somali in the process of decentralization, and this impeded Borana pastoralists' access to these important resources. On the other side interventions such as relief in the form of direct food aid or food for work, or rehabilitation such as restocking livestock have become permanent components of the household's income. They sustain livestock at higher levels, when herds recover from drought losses (boom and bust cycles of herd dynamics), and farmers do not need to sell their animals to cover their daily requirements. But these development interventions do not achieve longer-term impact on rangeland productivity, and as such they contribute to high stocking densities that aggravate negative impacts on the environment.

The impact of inappropriate development interventions and increasing grazing pressure has become severe. A rapid degradation through woody species encroachment can be observed in Dida Hara as well as in Web. As Dalle (2004) reported the area of Web (65\%) - with historical high inflow of cattle during dry seasons - was more affected by woody species encroached than Dida Hara $(50 \%)$ and the state of the foora was in between. The increasing grazing pressure affects especially the areas close to the encampments (warra), formerly preserved for the herds with lactating cows, young and weak animals. Borana pastoralists observed that insufficient grazing resources led to reduced conception rates and milk production.

\section{Effects on the Land-use System}

Encampments continued scattering in the former rainy season areas of Dida Hara, as the enforcement of the settlement directives, dongora seera, became increasingly difficult. In Web more impoverished households have settled in areas near the wells without respecting the traditional pasture regulations. Herd movements in both

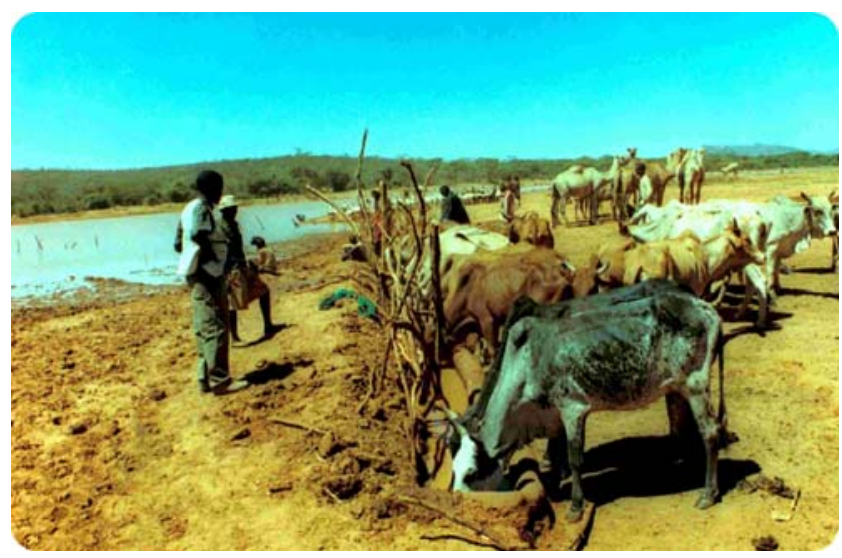

Fig. 7 Coordinated access to water at a pond in Dida Hara (merri) 
Table 1 Estimated seasonal stocking densities (TLU km ${ }^{-2}$ ), and coefficients of variation (\%) measured before the drought 1997/1998 in encampment clusters of Dida Hara and Web

\begin{tabular}{llllrrr}
\hline $\begin{array}{l}\text { Encampment } \\
\text { cluster/period }\end{array}$ & $\begin{array}{l}\text { Severe dry season } \\
\text { (Dec-Feb) } \\
\left(\text { TLU km }{ }^{-2}\right)\end{array}$ & $\begin{array}{l}\text { Big rainy season } \\
\text { (Mar-May) }\end{array}$ & $\begin{array}{l}\text { Small dry season } \\
\text { (Jun-Aug) }\end{array}$ & $\begin{array}{l}\text { Small rainy season } \\
\text { (Sept-Nov) }\end{array}$ & Mean & SE \\
\hline Dida Hara & $42.8^{\mathrm{a}}$ & $33.1^{\mathrm{a}}$ & $34.4^{\mathrm{a}}$ & $34.5^{\mathrm{a}}$ & $105.2^{\mathrm{b}}$ & $36.2^{\mathrm{a}}$ \\
Web & $338.2^{\mathrm{b}}$ & $101.3^{\mathrm{b}}$ & $147.5^{\mathrm{b}}$ & 2.2 & 12.4 \\
\hline
\end{tabular}

Means in rows followed by different subscripts are significantly different at $p<0.01$

areas became more short-term oriented to follow forage resources where they emerged.

However, in Web a high seasonal variability $(66 \%)$ in stocking densities can still be observed and on average a much higher stocking density (173 $\mathrm{TLU} \mathrm{km}^{-2}$ ) than the variability $(12 \%)$ and stocking density in Dida Hara (36 TLU km ${ }^{-2}$, Table 1). Web still has to accommodate incoming herds in search of water during dry seasons and droughts. These herds have to seek alternative grazing areas when the pastures near to the wells are depleted, whereas herds in Dida Hara can rely on easy access to water and abundant pastures.

The assessment of herd mobility at household level confirmed a higher mobility in Web than Dida Hara $\left(\chi^{2}\right.$ value $=16.7, p<0.01$, Table 2). Twenty percent of the herds in Web showed high mobility, whereas in Dida Hara high mobility was not found. In both encampment areas, the daily grazing radius for cattle (mata tixaa) was reduced from about 15 to $8 \mathrm{~km}$, reflecting higher pressure on more permanent grazing areas. Reduced and poorly coordinated mobility impedes the ecologically desirable variability in stocking densities, and has negative effects on rangeland condition.

The increasing human population density and further expansion of crop cultivation and forage banks that emerged within the encampment areas have reduced the available grazing resources and accelerated the grazing pressure (compare Figs. 8 and 9). The existing crop cultivation areas were much larger in Dida Hara than Web (about 863 ha versus 138 ha, respectively). Forage banks were also much larger in Dida Hara than Web $(2,641$ and 307 ha respectively). Borana pastoralists realised that the area for crop cultivation expanded preferably at bottomlands of fertile alluvial soils, and adsorbed most valuable grazing resources. Although crop cultivation in grazing areas was highly criticised by the pastoralists, and facing a high risk of crop failure or unsatisfactory harvests, cropping was considered to be one of the few means to improve food security.

The livestock per human ratio declined as the majority of the Borana pastoralists lost most of their livestock assets, through the recurrent droughts. The proportion of households who were able to subsist on livestock was reduced to only $12 \%$ after the last drought ${ }^{4}$. The droughts also contributed to unequal livestock ownership. In Dida Hara a minority of herd owners $(6 \%)$ kept large herds $(>150$ head of cattle) and reinvested in restocking after the drought, but most households fell into the lowest wealth level $(<50$ head of cattle). In Web all households had less than 50 head of cattle.

\section{Pastoralists' Responses}

In the early 1990s, after a change in government, ethnical warfare and a severe drought, resulted in an increase in the number of households keeping camels. Figure 5 shows that nearly all interviewed households in Web started keeping camels between 1986 and 2000, while some households in Dida Hara had already started in the seventies. Extrapolating these figures, up to now $34 \%$ of the households in Dida Hara and $40 \%$ in Web have adopted camel husbandry. According to pastoralists' information, most Borana herdsmen took over camels from neighboring Somali and Gabbra tribes. Camels are known to make better use of the available vegetation, to provide additional transport services and more reliable milk production. Adoption of camels also showed positive effects on households' herd mobility. Even if the relation between mobility and the adoption of camels was not significant during the drought, households with at least one camel were more mobile than others after the drought $(p<0.05)$. Keeping camels reflects Borana pastoralists' efforts in flexible herd management, and can also be interpreted as a response to ecological degradation and scarce grazing resources, thus a pragmatic compromise. Although camels have no traditional value in the Borana culture, they are now seen as indispensable for the pastoral production system and improve food security in the region. The productivity of camels in the Borana systems was however low and this reflects the distress caused by the droughts and a lack of management knowledge.

\footnotetext{
${ }^{4}$ Sandford and Habtu (2000) defined a minimum requirement of 3 TLU per African Adult Male Equivalent (AAME).
} 
Table 2 Household's herd movements (distance in $\mathrm{km} \mathrm{month}^{-1}$ ) in Dida Hara and Web during and after the drought

\begin{tabular}{|c|c|c|c|c|c|c|}
\hline & \multicolumn{3}{|l|}{ Dida Hara } & \multicolumn{3}{|l|}{ Web } \\
\hline & $\begin{array}{l}\text { During drought }(99 / 01) \\
\left(\mathrm{km} \mathrm{month}{ }^{-1}\right)\end{array}$ & After drought $(01 / 02)$ & Difference $(\%)$ & $\begin{array}{l}\text { During drought }(99 / 01) \\
\left(\mathrm{km} \mathrm{month}^{-1}\right)\end{array}$ & After drought $(01 / 02)$ & Difference $(\%)$ \\
\hline Median & 16 & 0 & -100 & 19 & 10 & -47 \\
\hline Min & 0 & 0 & 0 & 0 & 0 & 0 \\
\hline Max & 111 & 108 & -3 & 102 & 70 & -31 \\
\hline
\end{tabular}

Analysis of households' herd composition (number of animals) further revealed that households kept $28 \%$ small ruminants and $5 \%$ camels before the drought and $38 \%$ small ruminants and $7 \%$ camels after the last drought. The increased proportion of small ruminants after the drought was caused by the high cattle mortality during the drought, particularly in Dida Hara where cattle were more dominant. An increasing importance of goats can be prognosticated, especially where recurrent droughts increase the number of poor Borana households.

Pastoralists also changed their breeding preferences for cattle in response to the declining quality and quantity of grazing resources. Traditionally the Borana bred for two subtypes, the large-framed Qorti, considered here as the true type of the Ethiopian Boran cattle, and the smallerframed Ayuna. The pastoralists also named a third category of animals that exhibited features that were said to be intermediate between those of the qorti and ayuna. The Qorti sub-type has been known for its physiological adaptation to heat stress, drought tolerance, capacity to trek long distances, good mothering ability, docility and longevity. The Ayuna is a shorter type, smaller in body size, and was judged poorer in fertility, beef and milk production than the Qorti type. The body weight measurement confirmed a significant difference between adult Ayuna and Qorti cattle $(p<0.01)$, with the Qorti $(278$ and $317 \mathrm{~kg})$ being generally 41 and $51 \mathrm{~kg}$ heavier than the Ayuna (237 and $266 \mathrm{~kg}$ ), in dry and rainy season respectively (Table 3 ).

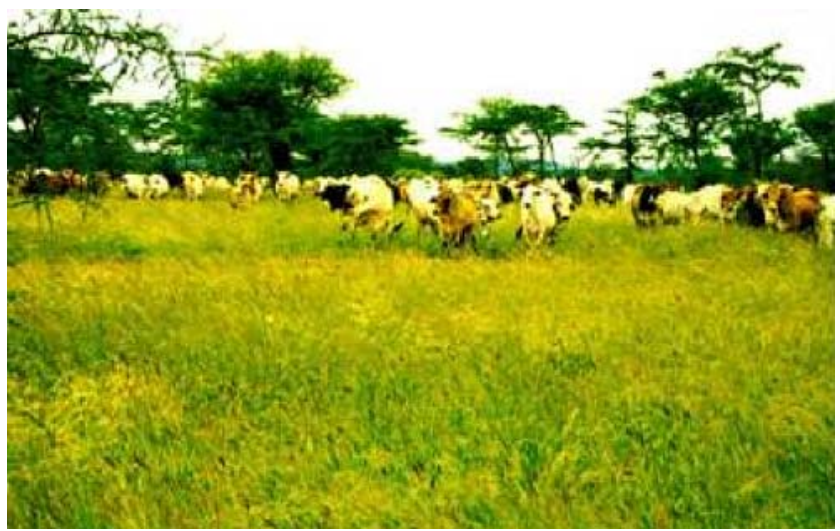

Fig. 8 One of the few remaining rainy season pastures
The average body weights of adult female qorti and ayuna were significantly different during both seasons $(p<0.01)$ with female qorti weighing about 39 and $43 \mathrm{~kg}$ more than the ayuna. This was also true for the males $(p<0.05)$, with male qorti being heavier by 69 and $104 \mathrm{~kg}$ than ayuna during the dry-season and the rainy-season, respectively. However, the intermediate type showed weights close to the ayuna.

According to the pastoralists the two sub-types of the Boran cattle have different geographical origins and habitats. Qorti was said to have originated from the grazing plains of the eastern part of Borana rangelands. The Ayuna type was said to have evolved from gradual introgression of genetic material from the highland cattle (Jemjem Zebu, Bale Zebu) into pastoral herds in the north of the rangelands. Under favorable rangeland conditions the pastoralists preferred the large-framed Qorti type. However, compared to the Ayuna, Qorti was observed to show lower tolerance to grazing pressure and poor-quality pastures and thus less competitive when grazing resources are scarce. Dida Hara was considered to be more appropriate for the Ayuna type, but Web was judged as still suitable for the Qorti. By selecting more for Ayuna Borana pastoralists thus adapted to the changes in their natural environment. According to pastoralists' perception, the maintenance of the true Ethiopian Boran breed sub-type, the Qorti is at threat.

In terms of a more controlled land use, Borana pastoralists attempted to develop restrictions upon crop cultivation and private grazing. The heavy encroachment of

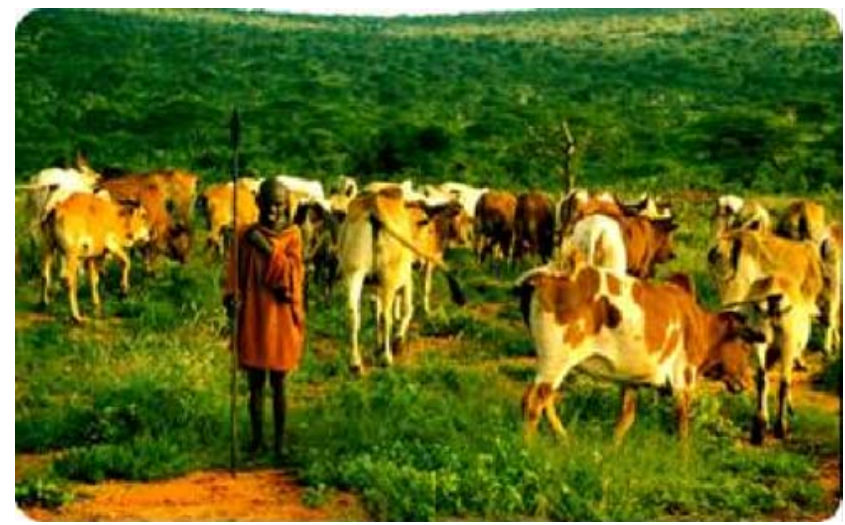

Fig. 9 Encampment cluster in Dida Hara, now heavily degraded 
Table 3 Average body weights $(\mathrm{kg})$ of adult Boran cattle from sample traditional herds by phenotype and sex measured during the severe dry and main rainy-seasons in Dida Hara and Web, 2001/2002

\begin{tabular}{|c|c|c|c|c|c|c|}
\hline \multirow[t]{2}{*}{ Type } & \multicolumn{3}{|c|}{ Severe dry-season (Dec-Feb) } & \multicolumn{3}{|c|}{ Main rainy-season (Mar-May) } \\
\hline & $\begin{array}{l}\text { Sample } \\
n\end{array}$ & $\begin{array}{l}\text { Mean } \\
(\mathrm{kg})\end{array}$ & SE & $\begin{array}{l}\text { Sample } \\
n\end{array}$ & $\begin{array}{l}\text { Mean } \\
(\mathrm{kg})\end{array}$ & $\mathrm{SE}$ \\
\hline \multicolumn{7}{|l|}{ All } \\
\hline Qorti & 112 & $277.7^{\mathrm{a}}$ & 6.1 & 148 & $317.0^{\mathrm{a}}$ & 5.2 \\
\hline Intermediate & 76 & $235.3^{\mathrm{ab}}$ & 4.0 & 50 & $282.0^{\mathrm{ab}}$ & 7.0 \\
\hline Ayuna & 86 & $237.0^{\mathrm{b}}$ & 6.4 & 71 & $265.7^{\mathrm{b}}$ & 4.5 \\
\hline Total & 274 & 253.2 & 3.6 & 269 & 296.9 & 3.6 \\
\hline \multicolumn{7}{|l|}{ Females } \\
\hline Qorti & 95 & $270.2^{\mathrm{a}}$ & 6.1 & 127 & $308.0^{\mathrm{a}}$ & 4.9 \\
\hline Intermediate & 66 & $231.0^{\mathrm{ab}}$ & 3.1 & 44 & $270.2^{\mathrm{ab}}$ & 5.0 \\
\hline Ayuna & 61 & $231.4^{\mathrm{b}}$ & 5.7 & 62 & $265.5^{\mathrm{b}}$ & 4.5 \\
\hline Total & 222 & 247.9 & 3.4 & 233 & 289.5 & 3.3 \\
\hline \multicolumn{7}{|l|}{ Males } \\
\hline Qorti & 17 & $319.1^{\mathrm{a}}$ & 19.0 & 21 & $371.2^{\mathrm{a}}$ & 17.6 \\
\hline Intermediate & 10 & $263.5^{\mathrm{ab}}$ & 21.5 & 6 & $368.0^{\mathrm{ab}}$ & 26.3 \\
\hline Ayuna & 25 & $250.4^{\mathrm{b}}$ & 16.9 & 9 & $267.4^{\mathrm{b}}$ & 19.0 \\
\hline Total & 52 & 275.4 & 11.7 & 36 & 344.8 & 14.0 \\
\hline
\end{tabular}

Means in columns followed by different subscripts are significantly different at $p<0.01$.

cropping into key grazing areas was recognised at the gumi Gaayo of 1996 as primary cause for the privatisation of rangelands. Nevertheless, the earlier acceptance of crop cultivation was confirmed, but only in limited areas and subordinate to the interests of pastoral land use. The private appropriation of rangelands by fencing and individual ownership of forage banks was forbidden, but cooperative grazing reserves to feed weak animals during dry season periods were accepted (Huqqa 1999). Yet, the directives of the gumi Gaayo 1996 were not fully implemented. Owners of large herds trespassed agreements through financial arrangements with the formal administration. Wars and droughts further impeded the enforcement of grazing directives. Disputes within the communities point to the dilemma of non-transparent decision making at the local level.

In a most recent attempt, pastoralists' committees involved the formal administration (PA) to re-strengthen controlled rangeland utilisation. The pastoral communities in Dida Hara and Web have realised that they have lost competence and power to regulate herd movements. Therefore, they initiated negotiations with the PA committees to re-establish dongora seera, the indigenous directives of restricted encampments. The main objective was to control access to pastures for the lactating herds near the encampments and to stop the ongoing scattering of encampments in the communal grazing areas. Linking the access to pasture to the location of the encampment would make households accountable for the grazing herds and land use. Only permanent encampments, managed by at least one adult woman, and in proper location along the line, should be allowed to graze lactating and non-lactating animals. Forage-banks should be restricted to areas commonly used by user-groups and no longer be fenced privately. The fencing of cropping areas should be limited to a maximum size of 1.5 ha per household and set up near the camps. The PA administration was requested to enforce the decisions at the community level and to support preserving community-controlled grazing areas. During the research phase it was observed that in most cases, encampments, crop cultivation fields and common grazing reserves were re-located within the agreed time frame.

\section{Discussion}

Applicability of IK-Based Management Strategies

The ecological degradation of the Borana rangelands affects livestock production and presents a high risk for food security. In accordance with Coppock (1994), it is concluded that in Borana rangelands the high grazing pressure over the last 30 years associated with a reduced level of herd mobility has contributed to the rapid degradation. Today, the Borana pastoralists are in a situation where the applicability of IK has been reduced, but they are more than ever challenged to develop strategies for more intensive rangeland utilisation, adapt quicker to increasingly scarce rangeland resources, and rehabilitate severely degraded rangelands.

The multi-stakeholder discussions confirmed pastoral rangeland management as best suited to improve the ecological conditions of Borana rangelands. The study 
supports the argument that herd mobility activates pastoralists' technological and organisational capacities in rangeland management with unpredictable rainfalls (Roe et al. 1998). Keeping mobile land-use strategies in practice maintains pastoralists' experimentation with the varying natural conditions. It also fosters pastoralists' cooperation and communication networks for controlled utilisation and maintenance of rangeland resources (Niamir-Fuller and Turner 1999). The study identified various initiatives by which Borana pastoralists preserved mobile land use and how they integrated other strategies for a more efficient rangeland utilisation. However, development and policy makers did not recognise the potential of building on these IK-based strategies, but have disturbed the applicability of pastoral rangeland management. As a consequence herd mobility has decreased, and as the study also showed practices directly related to mobility have been abandoned, e.g. rangeland evaluation by experienced scouts, information transfer and decision-making structures, and supplementary grazing for improved livestock production. A rehabilitation of IK-based rangeland management is therefore becoming increasingly difficult.

To enhance the productivity of rangelands, Borana pastoralists combined diversification and intensification strategies. By integrating camels pastoralists try to increase livestock production, exploit different feeding behaviour and endurance, and spread risk (Kaufman 2003). Keeping more camels sustains higher herd mobility, and this contributes to a better utilisation of rangelands and a better ability to resist droughts. Supporting mobility keeps remote grazing areas in production, that otherwise would degrade due to under-utilisation. Already, Borana pastoralists reported woody species encroachment in the Wayama rangelands that were contested by inter-ethnic conflicts. Camel husbandry is therefore an important element in revitalising herd mobility in the Borana rangelands.

In contrast, changes in pastoralists breeding preferences for the smaller framed cattle breed types and a higher share of small ruminants is a sign of distress. The study found that Borana pastoralists appreciated the smaller Boran cattle type for better adaptation to poor grazing conditions and higher grazing pressure. Small ruminants on the other hand can recover faster from drought, make better use of the local available vegetation and can be combined with crop production and alternative forms of income generation (Mace and Houston 1989). Herd diversification thus indicates a trend towards more sedentary land use for impoverished herd owners who are not able to afford continuous mobility. For better off herd owners it can be a tool to maintain mobility.

Land-use intensification by crop production and exclusive grazing has been debated across pastoral communities (van den Brink et al. 1995). Borana pastoralists originally adopted crop cultivation to sustain their own food security. This study identified crop cultivation as determinant of poorer and more sedentary household profiles, shown by a negative correlation of crop cultivation with keeping camels and a positive correlation with keeping small ruminants. Poverty induced crop cultivation undermines ecologically more appropriate mobile land-use strategies, and thus acts against IK-based management. It fuels conflicting interests between those pastoralists who can invest in mobile land use, and poor households who cultivate the land to receive immediate returns from their investment. The study further revealed that extension services had a strong impact on the expansion of crop cultivation. Dida Hara, where access to extension services was good, had a large expansion of crop cultivation, whereas Web had poorer access to extension service and less pronounced crop cultivation. Extension messages on cropping were neither linked to range management, nor did they include information on how to use crop residues for livestock feeding.

In agreement with Sandford (2006) it is concluded that the technical potential to improve crop cultivation and upgrade its value for livestock nutrition has not been sufficiently explored. Pastoralists currently lack the know how and the necessary inputs that would allow particularly poor households to gain from improved crop residues or selling them to those owners of larger herds, e.g. dual purpose crops or crop residue treatment as strategic feed resources. Similarly, uncontrolled expansion of fencedoff grazing areas and privatisation of key resource areas was highly contested. Yet, strategic improvement of jointly managed forage banks could be an effective means to increase herbage production in highly productive areas. Improved fodder bank management would require more investments in technical and institutional development, so that households with different land-use objectives would benefit. This would help to integrate functional IK with modern knowledge, and enhance farmers' ability to cope with periods of stress, e.g. transfer of information, inputs and technologies for dry season feeding of livestock.

Economic constraints restrict the revitalization of mobilitybased land-use. Households with larger flock sizes and cash income were more mobile, whereas poor households keep their herds rather stationary. In addition to that, the role of large cattle herd owners has changed. Traditionally, they were bound to contribute to public goods, e.g. rehabilitating impoverished households after a drought, maintenance of wells, military defence and cultural obligations (Helland 1982). Today, wealthier herd owners have started acting against the interests of the community by over-stocking the communal rangelands. They add grazing pressure particularly in the encampment areas (warra), where a higher number of poor households keep few animals and are not able to 
apply mobility. Socio-economic inequality is increasing after drought, as more households are being impoverished and only the wealthier households can sustain their herds. Economic development and drought mitigation are thus important to keep IK in practice (McCarthy 1998; Kamara et al. 2004). As Sandford (2006) postulates, investment in alternative sources of income are necessary to reduce the number of poor households depending on livestock and to preserve the livelihoods of those who are able to manage livestock in a sustainable way.

Prospects and Institutional Arrangements for Endogenous Development

Since the control of rangelands through limited water is no longer feasible, new regulations taking reduced mobility into account have to be put in place. The rangelands are currently jeopardized by de facto privatisation by wealthier and influential herd owners and non-sustainable exploitation by the poor. Strong external support is therefore required to strengthen and modernise those IK-based decision-making structures that could comply with the changed frame conditions, the only way for endogenous development.

The findings of this study attest that Borana pastoralists have the ability to adapt their organisational and management structures for more controlled land use, making use of their IK. They initiated joint consultations with the formal administration to re-establish a more coordinated land-use where IK-based institutions were not effective anymore. The joint efforts to negotiate conflicting claims indicate the potential of pastoralists' local strategies and institutions involved and are starting points for the development of more appropriate interventions (Behnke 1994; Turner 1999).

Borana pastoralists' priorities reflect the necessity to maintain communal rangeland management, but also to stricter control the number of pastoral households in the all year grazing areas near homesteads (warra) and transfer out of excess livestock. Pastoralists used restricted encampments as a tool to limit the animal density on these critical pastures. Establishing more binding regulations for pastures that secure the survival of herds reflects essential principals of the key resource concept (Scoones 1991; Reid et al. 2003). The communities' thereby try to preserve communal rangelands and avoid that few wealthier herd owners take over control (Sandford and Habtu 2000). McCarthy (1998: 31 ) has concluded, especially for the poor and marginalized households maintaining access to common rangelands “... is of utmost importance in reducing the riskiness associated with climatic variability".

The study substantiates that community-based institutions for controlled range management have a great potential to channel IK-based development (Watson
2003). Borana elders initiated a co-management with the PA committees, and requested the government as a facilitator to enforce their decisions, despite all deficiencies and a strong distrust. This confirms that legitimacy in negotiations between the traditional and formal institutions is critically important (Ngaido 2002). Traditional authorities that are recognized for their knowledge ability and integrity need to be reinstated for local land use planning, with access to improved management options. For the PA representatives, there is a strong need to develop election modes that are accepted by the pastoral communities, and to upgrade the local officials in range management and livestock knowledge. The structures for negotiating rangeland utilisation and maintenance need to include conflict mediation and arbitration between different interest groups (NiamirFuller and Turner 1999; Thébaud and Batterbury 2001). For instance, emerging privatisation in Borana can be attributed to conflicts of authority between the indigenous institutions and the PA. But privatisation did not automatically expand as the existing indigenous institutions still exerted some control.

The multi-stakeholder discussions reaffirmed an integration of IK-based range management and modern institutions and technologies to reinstate herd mobility. The traditional authorities need to agree on viable land use units and combine mobility-based livestock management with appropriate technologies that increase rangeland productivity, and have positive impact on poor livestock keepers. Research and development should focus on how to integrate the different knowledge systems and provide information that is relevant for joint decision-making processes. The following priority measures and institutional responsibilities should be revised and strengthened at the local level:

1. Restricted allocation of encampments, authorised by local land use committees (jarsa ardaa) and formal arbitration at the PA level;

2. Community controlled external grazing reserves (foora) and concerted measures for rangeland rehabilitation (e.g. rangeland burning, improving forage banks), coordinated by mobile herder committees (jarsa dheedhaa) and formal arbitration at woreda level;

3. Indigenous governance system ( $\mathrm{gadd} a$ ) for participatory monitoring and evaluation of the land-use planning process, especially after droughts or conflict-induced perturbations, backed up by capacity building and development planning at the regional and federal level;

4. Mediation between communities and in contact with outsiders by sensitised target group representatives (abba quaee, jallaba or hayyu), backed up by informed development agents;

5. Information systems on pasture quality, water availability and disease risk, targeting key persons and strategic locations for information transfer (e.g. range 
scouts, water managers, market places, watering wells and ponds);

6. New forms of organisation, such as breeder associations, producer cooperatives, marketing clubs.

To integrate pastoralists' IK and external expertise in development, negotiation platforms need to be established. Such platforms need to be designed and implemented by the stakeholders that identify and evaluate most appropriate options. More effectively shared information and better coordination between stakeholders can integrate viable indigenous institutions into planning processes and enhance technology development within a local context. Negotiation platforms that engage pastoralists' in decision-making structures and link them with higher level of governance can facilitate a more favourable environment for local innovations (Leonard 2004). Such structures need to mobilise pastoralists' own strength and resources, and ensure that pastoralists will be empowered to utilize external support to their advantage (Koehler-Rollefson 2007).

\section{Conclusions}

The possibilities of building on ELD principles for more sustainable management of Borana rangelands have not been sufficiently exploited. The study shows that pastoralists have transferred elements of indigenous organisation to the changing environmental conditions, and some indigenous networks persisted. Pastoralists have confirmed the necessity of mobility-based rangeland management at the multi-stakeholder workshops. Yet, reinstating the former mobility in range management is facing more challenges. A higher number of poor households depend on Borana rangelands, but are not in a position to apply pastoral range management, resulting in permanent grazing pressure on rangelands that are effectively shrinking. Ongoing socio-economic differentiation and the loss of negotiation networks and information flows will further reduce mobility, accelerating the loss of appropriate rangeland management strategies. The negative prospects are aggravated by limited livelihood options out of pastoralism. Without substantial support in migration out of pastoralism and to those who can apply herd mobility, the Borana rangelands are going to further deteriorate.

The study underscores the idea that in order to improve the livelihoods of Borana pastoralists, functional indigenous practices must be merged with effective external support. But local differences in pastoralists' predisposition for mobilitybased rangeland management need to be acknowledged. Future interventions need to account for changes in the respective ecological and socio-economic environment, as well as the history and impact of previous interventions. More emphasis is needed to evaluate local technical and organisational options for increased productivity of Borana rangelands. Those households that are committed to remain in pastoral production need to be engaged in identifying, testing and demonstrating the applicability of improved technologies within their respective context.

Recurrent droughts have forced many households to seek alternative income, as they can no longer survive on livestock alone. Endogenous development therefore also needs to address subsidiary income sources to release impoverished households from the dependence on livestock, without destroying their socio-cultural embedding. Strengthening linkages between livestock husbandry and alternative livelihoods, marketing, saving and processing facilities, as well as formal education and capacity building is necessary to enhance the productivity of pastoralists' livelihoods.

Acknowledgments We are grateful to the Tropical Ecological Research Programme/Gesellschaft für Technische Zusammenarbeit (TOEB/GTZ) and the Borana Lowlands Pastoral Development Programme (BLPDP/GTZ) for providing financial and logistical support. We are deeply indebted to the Borana pastoralist communities for their warm hospitality and willingness to share their knowledge. Many thanks are to Swathi Sridharan for editing the English. The comments and suggestions of two anonymous reviewers to an earlier draft of this paper are gratefully acknowledged.

\section{References}

Bayer, W., and Waters-Bayer, A. (2002). Participatory Monitoring and Evaluation (PM\&E) with Pastoralists: A Review of Experiences and Annotated Bibliography. Gesellschaft für Technische Zusammenarbeit (GTZ), Eschborn.

Behnke, R. H. (1994). Natural Resource Management in Pastoral Africa. Development Policy Review 12: 5-27.

Berkes, F., Folke, C., and Gadgil, M. (1995). Traditional ecological knowledge, biodiversity, resilience and sustainability. In Perrings, C. A., Maeler, K. G., Folke, C., Jansson, B. O., and Holling, C. S. (eds.), Biodiversity Conservation. Kluwer, Dordrecht, pp. 281299.

Blaikie, P., Brown, K., Stocking, M., Tang, L., Dixon, P., and Sillitoe, P. (1997). Knowledge in Action: Local Knowledge as a Development Resource and Barriers to its Incorporation in Natural Resource Research and Development. Agricultural Systems 55: 217-237.

Bruce, J., Hoben, A., and Ramato, D. (1994). After the Dergue: An Assessment of Rural Land Tenure Issues in Ethiopia. Wisconsin, Addis Ababa.

Coppock, D. L. (1994). The Borana Plateau of Southern Ethiopia: Synthesis of Pastoral Research, Development and Change, 1980 91. International Livestock Research Institute (ILRI), Addis Ababa.

Cossins, N. J., and Upton, M. (1987). The Borana Pastoral System of Southern Ethiopia. Agricultural Systems 25: 199-218.

Cossins, N. J., and Upton, M. (1988). Options for Improvement of the Borana Pastoral System. Agricultural Systems 27: 251-278. 
Dalle, G. T. (2004). Vegetation Ecology, Rangeland Condition and Forage Resources Evaluation in the Borana Lowlands, Southern Oromia, Ethiopia. Dissertation. Cuvillier Verlag, Goettingen.

Desta, S. (1999). Diversification of Livestock Assets for Risk Management in the Borana Pastoral System of Southern Ethiopia. Dissertation. Utah State University, Logan.

De Walt, B. R. (1994). Using Indigenous Knowledge to Improve Agriculture and Natural Resource Management. Human Organisation 53: 123-131.

Ellis, J. E., and Swift, D. M. (1988). Stability of African Pastoral Ecosystems: Alternate Paradigms and Implications for Development. Journal of Range Management 41: 450-459.

Flavier, J. M., de Jesus, A., and Navarro, C. (1995). The regional program for the promotion of indigenous knowledge in Asia. In Warren, D. M., Slikkerveer, L. J., and Brokensha, W. (eds.), The Cultural Dimension of Development: Indigenous Development Systems. Intermediate Technology Publications, London, pp. 479487.

Geerlings, E., Mathias, E., and Koehler-Rollefson, I. (2002). Securing Tomorrow's Food: Promoting the Sustainable Use of Farm Animal Genetic Resources: Information for Action. League for Pastoral Peoples, Ober-Ramstadt.

Gieampietro, M. (1997). Socioeconomic Pressure, Demographic Pressure, Environmental Loading and Technological Changes in Agriculture. Agriculture, Ecosystems and Environment 65: 201-229.

Helland, J. (1982). Social Organisation and Water Control Among the Borana. Development and Change 13: 239-258.

Helland, J. (2000). Institutional erosion in the drylands: The case of the Borana pastoralists. In Ahmed, M. L. (ed.), Pastoralists and Environment: Experiences from the Greater Horn of Africa. Organisation for Social Science Research in Eastern and Southern Africa (OSSREA), Addis Ababa, pp. 19-50.

Hogg, R. (1990). An Institutional Approach to Pastoral Development: An Example from Ethiopia. Pastoral Development Network. Paper 30d. Overseas Development Institute (ODI), London.

Homann, S. (2004). Indigenous Knowledge of Borana Pastoralitsts in Natural Resource Management: A Case Study from Southern Ethiopia. Dissertation. Cuvillier Verlag, Goettingen.

Homann, S., Rischkowsky, B., and Steinbach, J. (2007). The effect of development interventions on the use of indigenous range management strategies in the Borana Lowlands in Ethiopia. Land degradation and development. Published online 31 December 2007 in Wiley InterScience (http://www.interscience.wiley.com) doi:10.1002/ldr.845.

Huqqa, G. (1999). The 37th Gumi Gaayo Assembly. Gada: The Oromo Traditional, Economic and Socio-political System. The Norwegian Church Aid, Addis Ababa, Ethiopia.

Jahnke, H. E. (1982). Livestock Production Systems and Livestock Development in Tropical Africa. Kieler Wissenschaftsverlag Vauk, Kiel.

Kamara, A. (2001). Property Rights, Risk, and Livestock Development in Southern Ethiopia, Dissertation. Wissenschaftsverlag Vauk, Kiel.

Kamara, A., Swallow, B., and Kirk, M. (2004). Policies, Interventions and Institutional Change in Pastoral Resource Management in Borana, Southern Ethiopia. Development Policy Review 22: 381-403.

Kaufman, B. (2003). Differences in Perception of Causes of Camel Calf Losses Between Pastoralists and Scientists. Experimental Agriculture 39: 363-378.

Koehler-Rollefson, I. (2007). Endogenous Versus Globalized. An Alternative Vision of Livestock Development for the Poor. Discussion paper. League for Pastoral Peoples and Endogenous Livestock Development, Ober-Ramstadt.

Legesse, A. (1973). The Gada: Three Approaches to the Study of African Society. The Free Press, New York, USA.
Legesse, A. (2000). Oromo Democracy: An Indigenous African Political System. Red Sea Press, Asmara.

Leonard, D. K. (2004). The political economy of international development and pro-poor livestock policies: a comparative assessment. PPLPI working paper NO 12. Food and Agriculture Organisation of the United Nations (FAO), Rome.

Mace, R., and Houston, A. (1989). Pastoralist Strategies for Survival in Unpredictable Environments: A Model of Herd Composition that Maximizes Household Viability. Agricultural Systems 31: $185-204$

Mathias, E., Köhler-Rollefson, I., Geerlings, E., and van't Hooft, K. (2005). Endogenous livestock development: Can it help the poor? Tropentag, Bonn. Abstract available at (online) URL: http://www.tropentag.de/2005/abstracts/full/583.pdf.

McCarthy, N. (1998). An economic analysis of the effects of production risk on the use and management of common-pool rangelands. Socio-economic and Policy Research Working Paper edn. International Livestock Research Institute (ILRI), International Food and Policy Research Institute (IFPRI), Addis Ababa, Washington DC.

Ndikumana, J., Stuth, J., Kamidi, R., Ossiya, S., Marambii, R., and Hamlett, P. (2000). Coping Mechanisms and Their Efficacy in Disaster-prone Pastoral Systems of the Greater Horn of Africa. Effects of the 1995-97 Drought and 1997-98 El Niño Rains and the Response of Pastoralists and Livestock. International Livestock Research Institute (ILRI), Nairobi.

Ngaido, T. (2002). Pastoral land rights. World Bank's regional workshop on land issues in Africa, 29 April-2 May 2002, Kampala.

Niamir-Fuller, M., and Turner, M. D. (1999). A review of recent literature on pastoralism and transhumance in Africa. In NiamirFuller, M. (ed.), Managing Mobility in African Rangelands. The Legitimisation of Transhumance. Intermediate Technology Publications, London, pp. 18-46.

Oba, G. (1998). Assessment of Indigenous Range Management Knowledge of the Booran Pastoralists of Southern Ethiopia. Borana Lowland Pastoral Development Programme (BLPDP/ GTZ), Negelle.

ODPPB (2000). Loss Assessment Report in Lowland Woredas of Borana Zone. Oromia Disaster Prevention and Preparedness Bureau (ODPPB), Addis Ababa.

Pender, J., Ehui, S., and Place, F. (2006). Conceptual Framework and Hypotheses. In Pender, J., Place, F., and Ehui, S. (eds.), Strategies for Sustainable Land Management in the East African Highlands. International Food Policy Research Institute (IFPRI), Washington, DC, pp. 31-58.

Pratt, D. J., and Gwynne, M. D. (1977). Rangeland Management and Ecology in East Africa. Hodder and Stoughton, London.

Ray, C. (1998). Culture, Intellectual Property and Territorial Rural Development. Sociologica Ruralis 38: 3-20.

Reid, R. S., Thornton, P. K., and Kruska R. L. (2003) Loss and fragmentation of habitat for pastoral people and wildlife in East Africa: concepts and issues. 7th International Rangeland Congress, 26.07.-01.08.2003, Durban.

Roe, E., Huntsinger, L., and Labnow, K. (1998). High Reliability Pastoralism. Journal of Arid Environments 39: 39-55.

Roeling, N. (1994). Platforms for decision making about eco-systems. In Fresco, L. O., Stroosnijder, L., Bouma, J., and van Keulen, H. (eds.), The Future of Land: Mobilising and Integrating Knowledge for Land Use Option. Wiley, Chickester, pp. 385-395.

Sandford, S. (1983). Management of Pastoral Development in the Third World. Overseas Development Institute (ODI), London.

Sandford, S. (2006). Too many people, too few livestock: The crisis affecting pastoralists in the Greater Horn of Africa. (online) URL: http://www.future-agricultures.org/pastoralism_debate. html. 
Sandford, S., and Habtu, Y. (2000). Emergency Response, Interventions in Pastoral Areas of Ethiopia. Department for International Development (DFID), London.

Sayer, J. A., and Campbell, B. M. (2001). Research to Integrate Productivity Enhancement, Environmental Protection, and Human Development. Conservation Ecology 5: 232. (online) URL: http:// www.consecol.org/vol5/iss2/art32/.

Scoones, I. (1991). Wetlands in Drylands: Key Resources for Agricultural and Pastoral Production in Africa. Ambio 20: 366371.

Shongolo, A. (1995). The Gumi Gaayo Assembly of the Boran: A Traditional Legislative Organ in the Modern World. Zeitschrift für Ethnologie 119: 26-52.

Thébaud, B., and Batterbury, S. (2001). Sahel Pastoralists: Opportunism, Struggle, Conflict and Negotiation. A Case Study from Eastern Niger. Global Environmental Change 11: 6978.

Trebuil, G., Kam, S. P, van Keer, K., Shinawatra, B., and Turkelboom, F. (1995). Systems approaches at field, farm and watershed levels in diversifying upland agroecosystems: towards comprehensive solutions to farmers' problems. 2nd International Symposium on Systems Approaches for Agricultural Development: Meeting the challenge to balance required increases in food production with environmental protection. International Rice Research Institute (IRRI), Laguna.
Turner, M. D. (1999). Conflict, Environmental Change, and Social Institutions in Dryland Africa: Limitations of the Community Resource Management Approach. Society and Natural Resources 12: 643-657.

van den Brink, R., Bromley, D., and Chavas, J. P. (1995). The Economics of Cain and Abel: Agro-pastoral Property Rights in the Sahel. Journal of Development Studies 31: 373-399.

van't Hooft, K., Gebru, G., and Mathias, E. (2007). Focus. The Endogenous Livestock Development Network. People and Livestock: 5. (online) URL: http://www.pastoralpeoples.org/docs/ PALissue5Apr07.pdf.

Walker, B. H., and Noy-Meir, I. (1982). Aspects of the stability and resilience of savanna ecosystems. In Huntly, B. J., and Walker, B. H. (eds.), Ecology of Tropical Savannas. Springer-Verlag, Berlin, pp. 556-560.

Watson, E. E. (2003). Examining the Potential of Indigenous Institutions for Development: A Perspective from Borana, Ethiopia. Development and Change 34: 287-309.

Werner, T., Wilhelm, H., and Lex, A. (2001). Boorana Lowland/ Ethiopia 1:250000. Map. University of Applied Sciences, Berlin.

Westoby, M., Walker, B., and Noy-Meir, I. (1989). Opportunistic Management for Rangelands Not at Equilibrium. Journal of Range Management 42: 266-274.

World Bank. (1999) What is indigenous knowledge? (online) URL: http://www.worldbank.org/afr/ik/basic.htm. 